\title{
The only way to grow? Italian Business groups in historical perspective
}

Andrea Colli (Bocconi University), Alberto Rinaldi (University of Modena and Reggio Emilia), Michelangelo Vasta (University of Siena)

\section{Introduction}

A recent ( $21^{\text {st }}$ August 2013) article by the Financial Times ('Italian business: no way back') suggested, in quite an optimistic way, that the traditional, collusive attitude of Italian big business would progressively be crumbling under the pressure of international institutional investors. In a colourful way, the columnist used the image of the salotto buono (the fine-drawing room) to indicate the clubby, exclusive atmosphere surrounding the top-layer of Italian capitalism. After the Second World War, indeed, as stressed by most of the available research, the prominent Italian large companies tended to be interwoven by a dense network of cross-shareholdings, creating a coordinated structure allowing top owners/managers to keep firm control over their companies with limited investments.

While the cited article focuses mainly on the role played by Mediobanca (until a few years ago Italy's sole investment bank) and Assicurazioni Generali (Italy's largest insurance company) in designing and maintaining this architecture, research about Italian capitalism has stressed how, alongside this cluster of companies (resembling a sort of "horizontal" keiretsu), many vertical concerns existed. Large companies, in fact, tended to structure themselves as hierarchical business groups (henceforth BGs). These groups normally were headed by holding companies, often through sophisticated pyramidal structures able to amplify the benefits of financial leverage. This collusive attitude was thus permeating almost all the country's large companies, both private and Stateowned, which in this respect behaved not differently from the purely private ones. The rationale behind this strategy was to maximize control (and often tunnelling of resources) limiting the amount of resources directly invested by the owners/controllers, an absolute necessity when big business in capital intensive industries was concerned. To describe this, one of the most acute observers of Italy's industrial history, Napoleone Colajanni, coined the effective locution 'capitalism without capital'.

Italian business historians have so far analysed an increasing amount of evidence about this behaviour, pointing out the (few) pros and (many) cons of such a structure, ${ }^{2}$ suggesting how this collusive attitude has been somehow endogenous to Italian capitalism, as a result of a dramatic institutional failure in determining clear and transparent 'rules of the game'. ${ }^{3}$ However, this criticism has almost never been applied to forms of enterprise other from large private and stateowned firms. A large section (the majority, in numerical terms) of Italian companies has been thus genuinely immune from the growth strategies characterizing big business. For instance, networklike structures have been considered as distinctive characteristics of small firms in industrial districts, but as a (positive) symbol of the co-operative attitudes among local producers, bounded among themselves by both social and economic ties. ${ }^{4}$

At a closer look, however, this conventional wisdom shows some deficiencies and a different picture emerges. As this article shows, vertical BGs can today be found almost everywhere in the Italian industrial landscape, and involve companies of different size, legal status and sectors. Instead of vanishing or weakening, the $\mathrm{BG}$, as a governance and organizational device, seems to further root and diffuse among Italian enterprises as time goes by, that is over the nation's whole industrial history. All this calls for a deep investigation of the reasons which lie behind this stubborn persistence and growing relevance. This article aims at providing an in-depth analysis of the typologies, dynamics and rationales for the growing diffusion of BGs in Italy. In doing this, we combine the longitudinal approach typical of business history with a qualitative analysis providing a 
tentative taxonomy of the various typologies of BGs. Combining this evidence with that emerging from previous research, ${ }^{5}$ we put also forward some estimates of BGs' quantitative relevance over time and inside their specific categories.

This article is structured as follows. After this introduction, Section 2 presents an outline of the evolution of the Italian corporate system since the outset of Italy's modern industrialisation in late $19^{\text {th }}$ century. This provides a crucial framework for Section 3, which places an articulated taxonomy of BGs in the various forms of enterprise that can be found across Italy's industrial history. Section 4 explores the rationales for the wide use of BG, both across time and in each form of enterprise. Section 5 concludes.

\section{The evolution of the Italian corporate system}

Even if a latecomer in modern economic growth, Italy followed the global trends in the evolution of contemporary capitalism across the technological paradigms of the three industrial revolutions. Since the outset of the $20^{\text {th }}$ century, Italy made consistent progress in capital and energy-intensive industries. ${ }^{6}$ This process speeded up in the three decades following the Second World War and was fostered by the previous creation, in the 1930s, of a huge complex of State-owned enterprises (SOEs) which acted as Gerschenkron-type "substitution factors" to catch up the technological trajectory of the second industrial revolution. ${ }^{7}$ As a result, the weight (as a share of total output) and industry composition of Italian big business converged with those of the most industrialized countries. ${ }^{8}$

The oil crisis of the 1970s and the advent of ICT lowered the process of convergence of Italy's industrial structure with that of the leading nations. Since then, divergence started. ${ }^{9}$ The weight of big business - both in term of total assets and employment - decreased in Italy more than in the other advanced economies. ${ }^{10}$ Divergence concerns also the distribution of large firms across sectors, with a much smaller weight of ICT-related industries in Italy than in other developed countries, and, more generally, a lower capacity of firms to innovate. ${ }^{11}$

The decline of big business since the 1970s was accompanied by the rise of other forms of enterprise: small firms (often clustered in industrial districts), co-operative firms, municipalized firms, medium-sized enterprises (the Italian Mittelstand), and foreign-owned firms, which increased their share of both total employees and manufacturing output. ${ }^{12}$

Some of these forms of enterprise are strictly specific to the Italian case: small firms (from which most of the Mittelstand came out), co-operatives and municipalized companies correspond, in their diffusion, form and structure, to a particular set of social and institutional conditions which characterized $20^{\text {th }}$ century Italy. Conversely, other forms, such as big business and foreigncontrolled firms, are common to the other industrialized nations. However, Italian big business remained sharply different from its American and European counterparts as regards the degree of internationalization, the ownership and organizational structures, and the governance practices. ${ }^{13}$ By contrast, a wide range of policies were put in place to foster the expansion of the small firm sector, co-operative firms and municipalized companies. ${ }^{14}$

As said above, pervasive presence of BG is a common trait of growth of all forms of enterprise in Italy. In the next Section we show how the rationale for the use of the BG form constantly changed across forms of enterprise and over time according to technological and institutional changes.

\section{Typologies of Business Groups}

The main aim of this section is to offer a broad overview of the large diffusion of BGs in the Italian economy, providing a "new" taxonomy of groups' typologies. In Italy, the pervasive presence of 
BGs is not limited to big business, as usually happened in other countries, but it is common to most of the other forms of enterprise. Considering a set of variables, such as size, performance, legal forms, types of ownership and governance, in a recent edited book, Colli and Vasta ${ }^{15}$ identified seven different forms of enterprise which have contributed to the competitiveness of Italian capitalism along time. In all of these, but the foreign-owned, the BG structure is largely dominant. Looking at figure 1, which reports in the $\mathrm{x}$-axis the ownership characteristics of the firms and in the $y$-axis their size, we can see all the forms of enterprise taken into account in this section. In the upper part of the figure, we find the forms of enterprise for which the BG presence has been largely investigated. Firstly, we find the private big business (I quadrant) for which BGs have been largely dominant since the beginning of the $20^{\text {th }}$ century (section 3.1). In the II quadrant there are SOEs, which have represented, from the 1930 s to the 1990 s, a noticeable characteristic of the Italian capitalism (section 3.2). In the lower part of the figure, we find the forms of enterprise for which the presence of BGs has been underestimated by the literature. Close to the centre of the figure, we find the co-operative firms which - originally characterized by small size and considered as an alternative to the "capitalist corporation" - since the 1980s have developed peculiar BG structures (Section 3.3). In the III quadrant, there are the municipalized firms which, despite having conserved a public ownership, showed since the mid-1990s a growing propensity to be organized as BGs (Section 3.4). Finally, in the IV quadrant we placed the small firms, from whose seedbed, since the late 1980s, the Mittelstand, characterized by a large diffusion of the BGs, arose (Section 3.5).

Figure 1. Forms of BGs in 20th century Italy (circles size represent an estimate of their relevance)

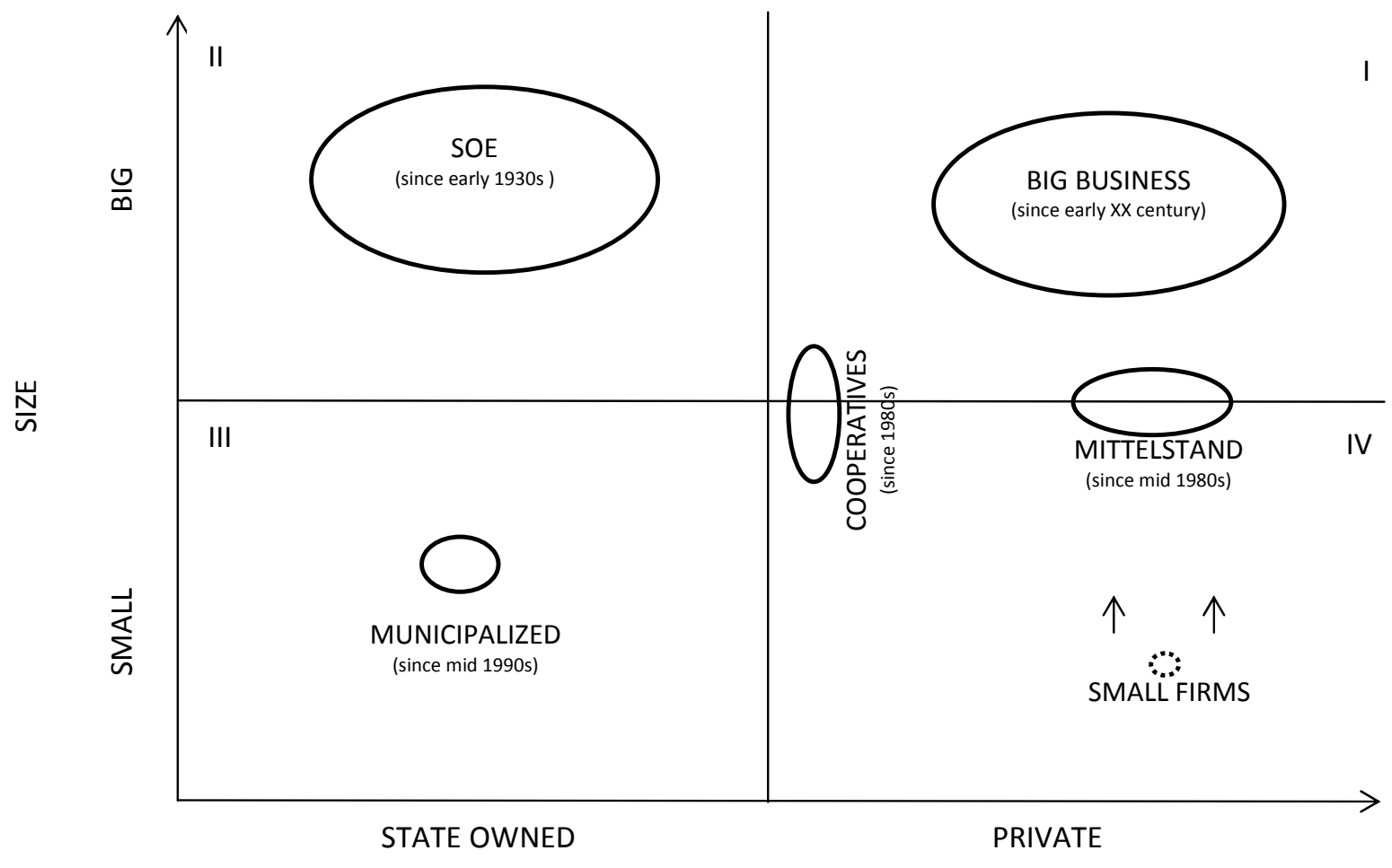

OWNERSHIP

\subsection{Private Big Business}

As anticipated in the previous section, even though a latecomer county, Italy closely followed the same pattern of development across the first and second industrial revolutions which characterized the other industrialized countries. Until the 1970s, alongside a vast population of small firms, big 
business active in capital intensive industries took root and accounted for a growing share of the nation's industrial output. Since the 1880 s both domestic and foreign entrepreneurs started successful ventures in fast-growing industries such as steel (Falck, founded in 1906), caoutchuch (Pirelli, 1872), electricity (Edison, 1889) and motor-vehicles (Fiat, 1899). The process of growth was, since the beginning, characterised by a strong tendency towards the progressive agglomeration of companies, more than pure processes of "internal growth".

Thus, agglomerations of companies resembling BGs were formed since the beginning of the 20th century, mainly in the form of cartels. ${ }^{16} \mathrm{~A}$ dense web of cross-shareholdings and interlocking directorates was designed to strengthen the mutual agreements among the companies belonging to the cartel, as for instance in the case of the "steel trust", created in 1903 by the main iron and steel producers which were in turn coordinated by Italy's two largest German-style mixed banks, the Banca Commerciale Italiana and the Credito Italiano, with the aim to control a relevant portion of the nation's steel production. ${ }^{17}$ As in other cases, ${ }^{18}$ trusts and cartels, in this phase, had as their main rationale the control of competition despite this might lead to the survival of inefficient companies. The result was the diffusion of "horizontal" cartels of collusive nature, often coordinated by the two largest mixed banks, not only in steel, but also in cotton, ${ }^{19}$ sugar refining ${ }^{20}$, and even in beverages production. $^{21}$

Military procurement for the First World War was for many of the existing "first movers" an unique opportunity for expanding the scale and scope of their activity. As a result, the leading industries of the second industrial revolution acquired a clear oligopolistic structure. ${ }^{22}$ The process of concentration was, almost without exceptions, managed through the creation of vertical BGs, i.e., a collection of legally independent entities linked among themselves and to a "parent" company usually controlled by a family or by a coalition hinging on one of the largest mixed banks - by cross-shareholdings and interlocking directorates. Examples range from Montecatini, a mining company, which undertook an ambitious downward integration, becoming the leader in fertilizers, to Fiat which became a powerfully integrated engineering and motor-vehicles company, and to Ansaldo, a huge vertically integrated "konzern" in steel and heavy mechanics. ${ }^{23}$ In this phase, vertical BGs of hierarchical nature started to diffuse together with horizontal ones. Moreover, the top management of the country's largest banks put in place sophisticated entrenchment strategies. The banks thus increased their shareholdings in a number of industrial companies, which, in their turn, were encouraged to buy shares of the banks. As a result, other horizontal, collusive groups emerged, pivoted by the main banks. ${ }^{24}$

In the interwar years, Italy made consistent progress in capital and energy-intensive industries of the second industrial revolution. In the 1920s, the vast majority of BGs continued to be formed through the progressive aggregation of companies, listed and not listed, active largely in the same industry or in related fields, very often in a logic of technologically driven vertical integration. Several examples can be found in the electricity industry. Here the concentration process took place through the acquisition of smaller companies (frequently active on a local or regional basis) by larger ones, which resulted in an oligopolistic structure on a super-regional basis. An exemplary case is that of Edison (Figure 2).

Even industrial companies expanded in the same way, both during and after the First World War. One (even if not the sole) driver of this process was the decision of de-taxing War super-profits of companies when reinvested, which strongly encouraged entrepreneurs to pursue "external growth" strategies. A case in point here is that of Fiat which expanded both through internal (a new, ultramodern factory, the Lingotto, was inaugurated in 1922) and external growth through the acquisition of controlling stakes in iron and steel companies in Piedmont already belonging to a cartel, the Gruppo Piemontese. In chemicals, immediately after the First World War, Montecatini started a steady expansion through the acquisition of its main competitors: Società Prodotti Chimici Colla e Concimi and Unione Concimi. During the following decade, Montecatini pursued an intense policy of acquisitions, both in related and non-related activities, due also to the pressures of the Fascist 
regime which encouraged the chemical concern to rescue companies on the verge of bankruptcy in exchange of protection in the internal market of fertilizers. ${ }^{25}$

Figure 2. The process of expansion of Edison, the Italian leader in electricity production and distribution (1912-1927).
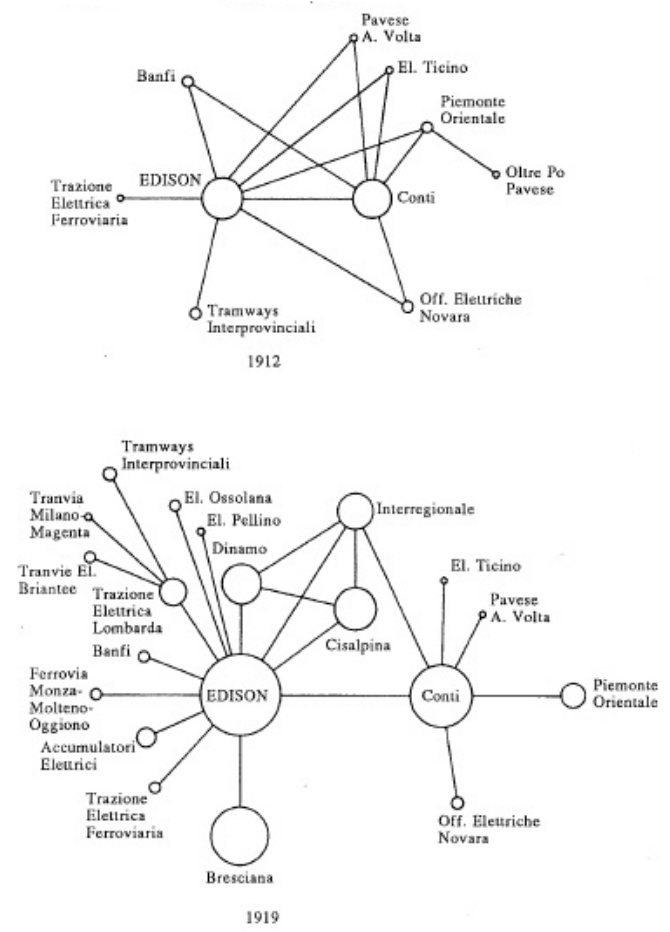

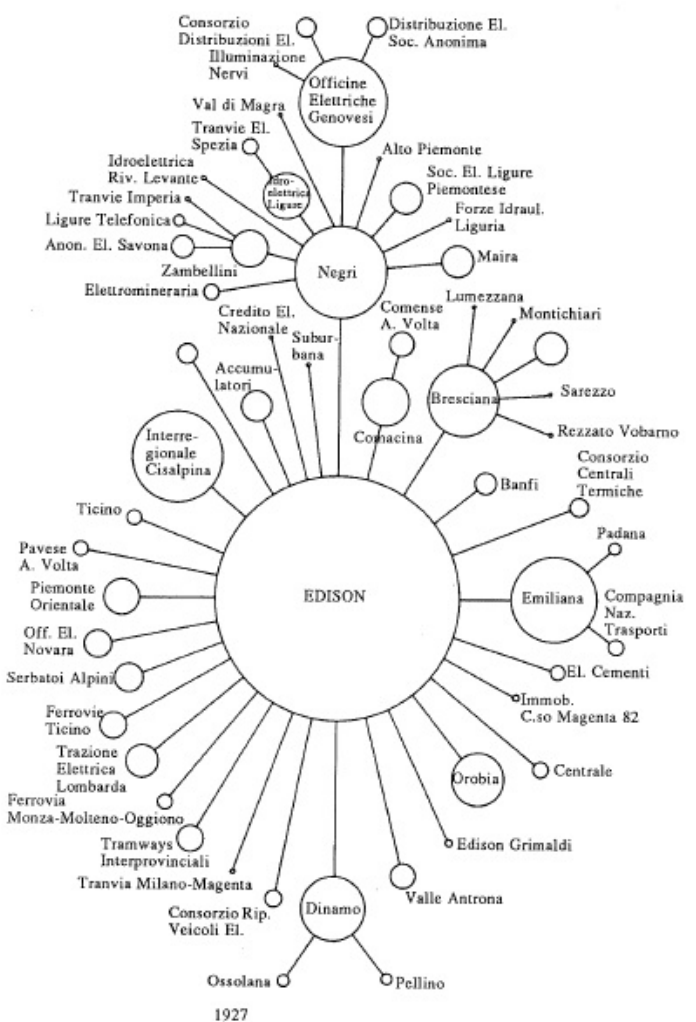

Source: adapted from Pavese, "Le origini", 142-3. The size of circles represents the size of nominal share capital of single companies in the group.

After the Second World War, the process of growth of big private companies went on along these lines. During the late 1950s and the 1960s private big business expanded basically through a mix of investments and endless acquisitions, which enlarged the boundaries of some of these groups enormously. Thus, the major electricity producer, Edison, was by the beginning of the 1960s (when the whole electricity industry was nationalized) a corporate "Moloch" composed by more than one hundred companies and subsidiaries, by far Italy's largest group in terms of revenues and market capitalization. $^{26}$

During the 1970s, a period characterised by crisis and the re-structuring of large companies, new BGs emerged, and others reshuffled their corporate architectures, for reasons completely different from those which drove BG expansion during the "Golden Age". Large companies in capital intensive industries were heavily affected by the crisis in their cost structure. In order to gain more flexibility, minimise control costs, dilute tensions in labour relation (and in some cases to proceed more easily with plant closures) most vertically-integrated companies followed a strategy of decentralization and fragmentation of the production chain. This practice was also encouraged by public incentives, which allowed each single subsidiary of a same group to have access to public funds for investments, as happened in the case of Società Italiana Resine (SIR), a chemical 
company which spun off hundreds of subsidiaries in order to obtain funds from the State for its investments in Sardinia. ${ }^{27}$

During the 1980s, big private firms continued to heavily rely on the BG form as common denominator in their corporate architectures. Again, the determinants of this process changed. First, the system of corporate taxation was modified, and intra-group transactions were no longer taxed something which reduced incentives to corporate integration. The second determinant was mainly of an exogenous nature, and involved a mounting effervescence in the stock market. Spinning off and listing subsidiaries became thus the most viable strategy, followed by all the major private groups Fiat, De Benedetti, Ferruzzi, in order to gather additional resources from the market. The configuration of Italian BGs was heavily influenced by this process. Pyramidal structures became now generalised; pure financial holdings, in their turn directly controlled by individuals or families, controlled a chain of operating companies, some of which listed. ${ }^{28}$ This process of unrelated diversification was in some way an "Italian" version of the conglomeration wave ongoing at international level. In Italy, this process went on longer and prolonged until the 1990s. In that decade, larger BGs further enlarged their boundaries thanks in particular to a massive sale sale-off of SOEs. In some cases, privatizations led existing groups to pursue unrelated diversification aimed at re-orienting their business towards the domestic market. This was the case of Benetton that acquired Società Autostrade, Italy's largest motorway company. ${ }^{29}$ However, other groups made their acquisitions in related activities, i.e., in steel (Lucchini, Riva, and Marcegaglia) and in chemicals (Mapei). ${ }^{30}$ Colli and Vasta provide a rough estimation of the quantitative relevance of big business groups in the Italian economy. According to their calculations, the first 15 BGs (most of which private) 'controlled' on average two thirds of the domestic joint stock companies' total assets and more than half of their share capital. ${ }^{31}$

\subsection{State owned enterprises}

The capital and scale-intensive sectors (steel, electricity and chemicals) typical of the second industrial revolution started their consolidation in the decades following the First World War. The role of the state in this process was very important, following a practice in which the state, since the unification, played an important and supportive role in fostering the Italian economic development through military procurement, protection and tariffs. The state direct involvement in the ownership of companies started in 1933 with the creation of the Istituto per la Ricostruzione Industriale (IRI), originally conceived as an emergency measure. However, after only few years, in 1937, IRI became a permanent institution and represented, for nearly seventy years, one of the pillars of the Italian corporate system . IRI was created in order to bail-out Italy's three largest mixed banks (Banca Commerciale Italiana, Credito Italiano and Banco di Roma), which were on the verge of collapsing due to the Great crisis of the early 1930s. IRI took over the banks' shareholdings and became the majority owner of a multitude of companies in a vast array of industries: i.e., real estate, steel, shipbuilding, mechanics, textiles, and utilities. The weight of this group in the Italian economy became soon enormous. Already in 1936, when it was still temporary, the IRI group accounted for $12.5 \%$ of the total capital of Italian joint stock companies. ${ }^{32}$ A complex architecture was designed to give some order to the vast array of companies under the control of IRI. The group was based upon a "super-holding" (IRI) under the direct control of the government. The superholding controlled some financial holdings which were characterised by sectorial specialisation: i.e., Finsider (steel), Finmeccanica (mechanics and engineering), Finelettrica (electric energy).

The boundaries of SOEs further expanded after the Second World War: IRI remained the main pillar of the system but a second pillar, the state energy super-holding, Ente Nazionale Idrocarburi (ENI), was founded in 1953, prolonged the experience of AGIP already founded in the 1920s. ${ }^{33}$

The weight of IRI group rose considerably and, in 1952, it represented almost one fifth of the total capital of Italian joint stock companies, while ENI group overcame 3 per cent.$^{34}$ These two big 
state-owned groups contributed considerably to Italy's catching up to the technological paradigm of the mass production during the "Golden Age". IRI gave a considerable contribution in the creation of infrastructures and heavily invested in capital-intensive industries, especially steel. Moreover, IRI also tried to provide inter-dependencies across companies in different industries. ${ }^{35}$

At the same time, ENI, which had a similar vertical organisation, re-inforced by interlocking ownership across the companies of the group, was addressed to meet the country's needs in the fields of energy. State-controlled groups showed a number of differences from private ones. These concerned in particular $i$ ) the use of more sophisticated multi-level organisational architectures; and ii) the presence, particularly inside IRI, of strong linkages with the country's largest banks. ${ }^{36}$

In the 1970s, the oil crises and the rise of a new technological paradigm, based on ICT, opened a new scenario for the Western economies. Italy was severely hit by this new situation and SOE groups were increasingly burdened with special social objectives, such as prompting the industrialization of the backward South or rescuing distressed companies. The structure of Italian corporate system turned noticeably after the oil crisis and the new technological paradigm speeded up the crisis of the SOEs. This degenerated in the 1980s due to the excessive grip of politicians on SOEs and the consequent erosion of the "mission" culture of SOE managers. ${ }^{37}$ Someway paradoxically, at the beginning of the 1980s, the boundaries of the SOE sector were the largest in Italian history, ${ }^{38}$ but the final crisis of the entire system was close.

During the 1990s, massive privatizations reduced the weight of SOEs groups opening a new era of state entrepreneurship in Italy. IRI was dismantled and closed down even if the state retained control of national champions in some strategic sectors as energy, telecommunications and defence. The stock of these companies was also partially sold off to raise funds from private investors. At the end of the century, the diffusion of state owned groups within the Italian corporate economy was considerably reduced.

\subsection{Co-operatives}

If the diffusion of BGs among Italian big business, both private and state-owned, has been widely investigated, this was not the case for BGs in other forms of enterprise. Among the latter, cooperatives stand out. The first co-operative firms in Italy were founded in the late $19^{\text {th }}$ century. The plurality of inspirational ideals in the Italian co-operative movement led to the formation of separate umbrella organisations: Legacoop (leftist), Confcooperative (catholic), and Agci (liberal). ${ }^{39}$ Their tasks are manifold: new co-operatives promotion, strategic marketing, ethical control of the affiliated firms, know-how and human resources circulation, internal conflict resolution and coordination of the major strategic decisions, lobby at the local, national and European government level. ${ }^{40}$

Until the 1970s, co-operatives played a marginal role in the Italian economy: nearly all co-ops were small and inefficient and survived only thanks to political protection. However, since the 1970s the co-operative sector - contrary to the other major advanced economies ${ }^{41}$-went through constant expansion : from 10,000 co-ops in 1971 to 63,000 in 2010; from $2 \%$ of the nation's employment in 1971 to $6.4 \%$ in 2010 , a value higher than in any other European country. ${ }^{42}$

The larger co-ops experienced the most outstanding growth. As a result, in 2010 co-ops accounted for 10 per cent of all the enterprises with more than 500 employees. Larger co-ops have become the market leaders in Italy in some sectors, i.e., large scale retailing, constructions, and agro-food. Such a result was probably favoured by the capitalist sector's (especially private big business') failure to achieve the power retained in other countries, which left co-operatives with more room for expansion.$^{43}$ The growth of larger co-ops was first pursued through mergers of existing co-ops and then, since the mid-1980s, above all through the formation of BGs that encompassed both co- 
operative firms and joint stock companies controlled by a co-op. This growth strategy was adopted principally to overcome capital constraints. In fact, under-capitalisation was the major weaknesses of co-operative firms, which constrained their growth. This was due to the lack of a market for cooperative shares, from which the expected future flows of profits could increase their value for the shareholders. A paramount role to boost the creation of co-operative groups was played by the 1983 law that granted co-operatives the permission to own capitalist corporations. This allowed many coops to grow by becoming the parent-company of several joint-stock companies which were used to attract capital from the market. ${ }^{44}$ Thus, in 1998 there were 64 co-ops members of Legacoop (Italy's largest umbrella organisation) that presented a consolidated balance sheet; in 2003 the corresponding number rose to 96 . The value of their shareholdings surged from 1,354 to 2,793 million euros. ${ }^{45}$

An exemplary case is Granarolo, a consortium set up in the 1950s by some milk producing co-ops of Bologna. Its plants, machinery and brands were owned partly by the consortium and partly by the milk producing co-ops that had constituted it. In 1991, they created a joint-stock company with the same name, to which the assets of the consortium and of the co-operatives were transferred. This became the company designing the strategy for the entire group. In 1998, the original co-operatives were gathered in a single consortium, Granlatte, which became the owner of the joint stock company, together with a second consortium, Cooperlat, which joined in 1999. In this way, it was possible to resort to more substantial bank loans and to issue bonds, without the traditional disadvantages produced by the co-operative legal form. By 2010, the group was articulated on four levels, of which the second was made up of two cooperative consortia, which, directly or indirectly, owned 11 companies. The group maintained its cooperative character, because 68 per cent of the milk processed came from its member co-operatives. In 2004, Banca Intesa, one of Italy's largest banks, acquired 19.8 per cent of the capital of Granarolo. ${ }^{46}$

Most co-operative BGs pursued related diversification and these were the most successful. There were also some cases of unsatisfactory unrelated diversifications, as Cmb of Carpi, a co-operative construction giant which in the 1980s diversified in the ailing local textile industry. This venture ended in a massive loss as $\mathrm{Cmb}$ lacked the know-how to manage the newly acquired textile subsidiaries. $^{47}$

\subsection{Municipalized companies}

Another form of enterprise typical of the Italian corporate system appeared at the beginning of $20^{\text {th }}$ century. The 1903 Municipalisation Act enabled municipalities to manage public services through the Azienda Municipalizzata (municipalized company), an autonomous public-law entity emanating directly from the municipality itself. Since then, many municipalities, especially in the North and the Centre, set up municipal companies to provide services such as electricity, gas and water supply or public transport acting as monopolists in the territory of the municipality.

The post-Second World War years saw a substantial expansion of the area of municipalized companies, prompted principally by the local governments controlled by left-wing parties. Nonetheless, municipal companies remained small as their growth was curbed by the impossibility to operate outside of the territories of the municipalities that owned them. ${ }^{48}$

In 1990, a new Law on Local Authorities spurred many important changes in the municipal companies. The Law considered the Azienda Speciale (special company) - whose managers enjoyed greater control of the firm - as the most suitable legal and administrative form for managing local public services. It was directed towards the rationalization of management strategies and instruments, thus indicating a range of privatisation solutions. ${ }^{49}$

In the 1990 s, a new legislation was also passed in the utility sector to introduce competition in the retail segment and a new regulation of access to market segments requiring significant investments 
through competitive tendering procedures. Municipalized companies could now sign contracts to obtain energy supplies at lower prices and could consider managing other city and regional distribution networks. Partnerships with other private or public companies allowed them to enlarge their range of action into other territories from the original ones. At the same time, customers were no longer guaranteed and had to be continuously won, especially industrial ones. ${ }^{50}$

This new competitive environment pushed many municipalized companies to turn into public limited companies, that pursued multi-utility strategy aimed at diversifying services and enlarge their territorial base. Municipalities remained the most important blockholder in these companies, followed by private owners and by regional, provincial and state organisms. Some of the new multiutilities were listed in the Stock Exchange, starting from Amga of Genoa in 1996. A process of consolidation of municipalized companies led to the formation of BGs that operate at a regional or supra-regional level. These are constituted by a parent-company (usually a holding company) which controls several operating companies. The latter are specialized in the managing of the individual utilities, in upstream or downstream activities, or in serving the territory of the single municipalized companies that joined the BG. ${ }^{51}$

The BG form proved very effective in increasing the leverage to finance related multi-utility diversification and territorial expansion, but also to accommodate the pressures of the shareholders and stakeholders of the territories (the municipalities) in which the constituent companies (the municipalized companies) were located. This is not devoid of repercussions on the performance of such companies. In fact, a recent study has shown that the large presence of politicians in the board of directors of Italian utilities has an inflationary effect on employment and harms the accounting performance of these companies. ${ }^{52}$

\subsection{The Italian Mittelstand}

Starting from the late 1980s, an important evolution in the Italian economy has been the growing relevance of medium-sized enterprises, the Italian Mittelstand. At the beginning of the $21^{\text {st }}$ century, more than 1,500 businesses with annual sales between 150 million and 1.5 billion euros operated in Italy. These Mittelstand companies often emerged from the entrepreneurial seedbed of industrial districts. The increasing pressure of globalization determined a restructuring of many Italian industrial districts, with the rise of lead firms that pursued dimensional growth and accelerated internationalization with the establishment of trading and production subsidiaries abroad. Most of these Mittelstand companies became leaders in world-sized market niches especially in traditional sectors, such clothing, luxury goods, and various branches of the so-called 'Made in Italy', in some case they are also specialized in machine tools or in other more advanced sectors.

Generally, these companies went on sharing many of the features of the traditional small firms typical of industrial districts, i.e., family ownership, centralized management and a scarce attitude towards path-breaking innovation. ${ }^{53}$ The emergence of this model as a successful form of enterprise is someway puzzling because, in a long-term perspective, 'mediumness' is a transient condition. By looking at the whole $20^{\text {th }}$ century, only very few Italian firms found their optimal size within the medium-size group: it seems to confirm the traditional difficulty to grow faced by many Italian firms which, after having become medium-sized, in most cases returned to being small. ${ }^{54}$

The growth of Mittelstand companies in recent years was pursued through the creation of BGs based upon a multi-subsidiary system. The owner-family is the source of skills and resources most of these BGs have relied upon to provide finance, labour, and know-how. The structures of these BGs mirror their historical evolution. The first, original nucleus of the enterprise has transformed itself into a family-controlled financial holding company, presiding over a large number of unincorporated subsidiaries active in related activities, both in the home market and abroad. The BG form is the result of both the minimisation of administrative and coordination costs and of the growth strategy pursued by these enterprises. In fact, most Italian Mittelstand companies grew (both 
in the domestic and foreign markets) usually by means of the acquisition of existing smaller companies which maintained their strategic and administrative independence. The operative companies (both productive and commercial) are often run by relatives or by professional managers strictly linked to the family to whom is often assigned also a minority shareholding. In other cases the external growth is pursued leaving to the existing management (sometimes the former owners) the responsibility to run the activity. ${ }^{55}$

Thus, the rise of these Mittelstand BGs appears the result of the internationalisation strategies of the most dynamic firms to face globalization. This led to an original blending of technologies of the first and of the third industrial revolution. In fact, most of such BGs have their core business in the typical first industrial revolution 'Made in Italy' sectors, but in order to pursue successful internationalisation they massively used ICT-based technology to adapt to rapidly shifting markets and to manage offshore outsourcing and a worldwide network of trading subsidiaries. ${ }^{56}$ In this case, the rationale for the use of the $\mathrm{BG}$ form was not the increase of leverage, as it is shown by the fact that the architectures of such BG are usually very simple, as most of these BGs have only a twolayer structure (a holding companies directly controlling several operating companies). ${ }^{57}$ Instead, the creation of BG served principally to acquire, retain, and properly use technical and managerial capabilities, by giving the managers of the subsidiaries a wider autonomy than the division heads of a M-form enterprise.

An exemplary case is that of Wam, a firm set up in 1968 as owner-run company by Vainer Marchesini - at that time a 22-year-old technician - in the mechanical engineering district of Modena to produce cement screw conveyors. Starting from the 1980s, Wam pursued an internationalization strategy that enabled it to become the world leader in the production of bulk material handling and dust filtration machinery. By 2007, the company was still run by its founder. The holding company Wamgroup - owned by the Marchesini family - was at the head of a BG which consisted of 45 companies: seven Italian manufacturing companies, nine foreign manufacturing companies (in the US, China, Australia, India, Brazil, Spain, Romania and Croatia), 27 foreign trading companies, one Italian real estate company and one Italian service companies. The group employed 1,700 workers and had a turnover of about 200 million euros. ${ }^{58}$

\section{Why growth through business groups?}

After having proposed a taxonomy of different BGs, this section discusses the reasons why Italian entrepreneurs (in all forms of enterprise) preferred to grow by creating BGs rather than big M-form corporations.

A first reason refers to $\mathrm{BG}$ as an instrument to enhance the control of the dominant shareholders with a limited investment of their own resources, an explanation which goes back to Hilferding. ${ }^{59}$ The diffusion of such a control enhancing mechanism implies in its turn the presence of a favourable legislation, or at least the absence of rules limiting the leverage effect. Above all - and in the case of Italy this seems particularly evident - the limits in the dimension and in the quality of the domestic financial markets, and the absence of specialized financial institutions, play a relevant role in incentivizing the formation of BGs through which the dominant shareholders obtain resources from the stock market without losing much of their decisional power. This was the main reason that pushed private big business and SOEs to create multi-layered BGs to catch up the technological paradigm of the second industrial revolution and, more recently, for the creation of BGs by co-operatives and municipalized companies.

Secondly, BGs provide more freedom and incentives to the subsidiaries' management, something which is more difficult in an integrated organization in which the headquarter has a strong grip on the divisions and in which the management's decisional power is severely constrained. This becomes particularly evident in the case of the Italian Mittelstand, due to the key role played in it by 
the owner-family: BGs allow to separate power and responsibilities across the members of the family in this way avoiding conflicts among them. In other cases, the BG is an instrument through which is possible to take over companies without integrating them, and avoiding the risks of a complete turnaround in their management - especially in the case of successful ones.

A third possible explanation for the diffusion of BG lies in the fact this form proved very effective in accommodating the pressure of shareholders and stakeholders, as it was the case for municipalized companies.

In other cases, fiscal policies play a relevant role, especially when they neutralize the difference between BG and other forms of organization (i.e., the M-form). Large BGs can have a better access to credit than large integrated organizations, at least from the profitable subsidiaries. Moreover, the BG structure better allows the tunnelling of resources from companies where the holding has low cash rights to companies where it has high cash rights. Another peculiar situation is where the multiplication of subsidiaries is due to the possibility to obtain resources in the form of incentives and subsidies from public institutions. In the case of Italy, the policies aiming at fostering the industrialization of the South were largely based on the concession of tax exemptions, loans, but also of direct subsidies. This led some entrepreneurs to create BGs characterized by a wide number of subsidiaries, each one separately asking for public support.

In sum, the BG as a governance system looks particularly flexible, adapting itself to different ownership and market conditions. In absence of obstacles of legal or fiscal nature, this flexibility is probably the main reason for its resilience. This points to the institutional determinants of its adoption, i.e., why the policy-maker incentivized, or at least did not hinder, the formation of BGs. An analysis of this is beyond the scope of the present article. We can suggest that this was probably a consequence of the fact that mass-based political parties became soon the most prominent political actors in Italy, which profoundly conditioned institution building. These parties prevented the creation of constituencies alternative to them. Powerful widely-held big business independent from politics could play this role of alternative constituency. Politics thus pursued institution building in order to curb their growth. By contrast, growth through the use of mechanisms that amplified financial leverage, such as BGs, was preferred. In fact, this created a situation in which the dominant shareholders must continuously bargain favourable regulation and access to resources with the political power, thereby making them more dependent on politics. ${ }^{60}$

\section{Conclusions}

In this article, we put forward a series of conceptual contributions in current research about BGs, looking at the Italian case in a historical perspective.

A first, important point is that, as the Italian case shows clearly, BGs are not an organizational form proper of developing countries or of economies in their very early stage of development. In the course of its evolution from a peripheral economy to one of the most industrialized country of the world, the Italian corporate system has been constantly populated by BGs, dominant in their diffusion and economic relevance over other organizational structures.

Secondly, this article shows that BGs are present not only among large firms, but in almost all the dimensional categories and juridical forms. This challenges the conventional wisdom which assumed that BGs are simply an (maybe less, or not) alternative to the M-form characterizing big business around the world.

Third, this article demonstrates that vertical BGs, often identified with family ownership, can in fact be diffused also among non-family firms, ranging across a wide spectrum of ownership forms, as co-operatives, municipalized companies, and SOEs . 
Our contribution suggests also how longitudinal analysis is essential to understand in-depth the whole phenomenon of the diffusion of BGs in a country. The BG as a governance system looks particularly flexible, adapting itself to different ownership and market conditions and local contexts. In absence of obstacles of legal or fiscal nature, this flexibility is probably the main reason for its resilience. 


\section{References}

Amatori, F., "Italy: the tormented rise of organizational capabilities between State and markets", in Big Business and the Wealth of Nations, edited by A. Chandler, F. Amatori and T. Hikino, New York: Cambridge University Press, 1997: 246-276.

Amatori, F., "Entrepreneurial Typologies in the History of Industrial Italy: Reconsiderations", Business History Review, 85, 2, (2011): 151-180.

Amatori, F., and F. Brioschi, "Le grandi imprese private: famiglie e coalizioni", in Storia del capitalismo italiano. Dal dopoguerra ad oggi, edited by F. Barca, Rome: Donzelli, 1997: 117-53.

Amatori F. and B. Bezza (eds.), Montecatini. Capitoli di storia di una grande impresa, Bologna: Il Mulino, 1990.

Amatori, F. and A. Colli, Impresa e industria in Italia dall'Unità ad oggi, Venice: Marsilio, 2000.

Amatori, F. and A. Colli, "European Corporations: Ownership, Governance, Strategies and Structures. A Review of Five Countries: United Kingdom, Germany, France, Italy and Spain", in The European Enterprise: Historical Investigation into a Future Specie, edited by H. Schröter, Berlin: Springer Verlag, 2008: 23-36.

Amatori, F., M. Bugamelli and A. Colli, "Italian Firms in History: Size, Technology and Entrepreneurship", in The Oxford Handbook of the Italian Economy (1861-2011), edited by G. Toniolo, Oxford: Oxford University Press, 2012: 455-484.

Barca, F. and Trento S.. "State Ownership and the Evolution of Italian Corporate Governance" Industrial and Corporate Change 6 (1997): 533-59.

Battilani P. and H. Schröter (eds.), The Cooperative Business Movement, 1950 to the Present, New York: Cambridge University Press: 2012.

Battilani, P. and V. Zamagni, "Co-operatives (1951-2001)", in Forms of Enterprises in 20th Century Italy. Boundaries, Structures and Strategies, edited by A. Colli and M. Vasta, CheltenhamNorthampton: Elgar, 2010: 273-293.

Battilani, P. and V. Zamagni, "The Managerial Transformation of Italian Co-operative Enterprises 1946-2010”, Business History, 54, 6 (2012): 964-985 .

Battilossi, S. "Mercati e concentrazione", in Storia d'Italia. Annali 15. L'industria, edited by Franco Amatori et al., Turin: Einaudi, 1999: 275-345.

Becattini, G., Industrial Districts. A New Approach to Industrial Change, London: Elgar, 2004.

Bertagnoni, G. (ed.), Una storia di qualità. Il gruppo Granarolo fra valori etici e logiche di mercato, Bologna: Il Mulino, 2004.

Binda, V., and A. Colli, "Changing Big Business in Italy and Spain 1973-2003. Strategic Responses to a New Context", Business History, 53, 1 (2011): 14-39.

Bonelli, F., Lo sviluppo di una grande impresa in Italia. La Terni dal 1884 al 1962, Turin: Einaudi 1975. 
Brioschi, F., L. Buzzacchi and M.G. Colombo, Gruppi di imprese e mercato finanziario: la struttura di potere dell'industria italiana, Rome: NIS 1990.

Castronovo, V., FIAT, 1899-1999. Un secolo di storia italiana, Milan: Rizzoli 1999.

Colajanni, N., Il capitalismo senza capitale, Milan: Sperling \& Kupfer, 1991.

Colli, A., Il quarto capitalismo. Un profilo italiano, Venice: Marsilio, 2002.

Colli, A., "A Tale of Lost Chances. A Short History of Corporate Governance and Ownership in Italy", Corporate Ownership and Control, n. 6, 2008.

Colli, A., “The Italian Brewing Industry, c. 1815-1990”, in The Dynamics of International Brewing Industry since 1800, London: Routledge 1998: 32-58.

Colli, A. and M. Vasta, "Large and Entangled. Italian Business Groups in the Long Run", Business History, forthcoming.

Colli A. and M. Vasta, "Introduction: Forms of enterprise in 20th century Italy", in Forms of Enterprises in 20th Century Italy. Boundaries, Structures and Strategies edited by A. Colli and M. Vasta, Cheltenham-Northampton: Elgar, 2010: 1-21.

Colli, A. and A. Rinaldi, "Institutions, Politics and the Corporate Economy", Quaderni del Dipartimento di Economia Politica e Statistica, Siena: Università degli Studi di Siena, n. 664, November 2012.

Coltorti, F., "Medium-sized firms, groups and industrial districts: An Italian perspective", in Handbook of Industrial Districts edited by G. Becattini, M. Bellandi and L. De Propriis, Cheltenham-Northampton: Elgar, 2009: 441-456.

de Cecco, M., "La politica italiana delle privatizzazioni," in Le privatizzazioni nell'industria manifatturiera italiana, edited by M. Affinito, M. de Cecco and A. Dringoli, Rome: Donzelli, 2000: xv-xxxvii.

Fari, S., and A. Giuntini, "Public Utilities in the 20th Century"" in Forms of Enterprises in 20th Century Italy. Boundaries, Structures and Strategies edited by A. Colli and M. Vasta CheltenhamNorthampton: Elgar 2010: 185-203.

Fear, J., "Cartels" in The Oxford Handbook of Business History, Oxford: Oxford University Press, 2008: 268-92.

Federico, G., "Italy 1860-1940: a little-known success story", Economic History Review, 40 (1996): 764-786.

Giannetti R. and M. Vasta (eds.), Evolution of Italian Enterprises in the 20th Century, HeidelbergNew York: Springer Verlag 2006.

Giannetti R., and M. Vasta "Big Business (1913-2001)", in Forms of Enterprises in 20th Century Italy. Boundaries, Structures and Strategies edited by A. Colli and M. Vasta CheltenhamNorthampton: Elgar 2010: 25-51. 
Hilferding, R., Das Finanzkapital, Vienna: Wiener Volksbuchhandlung, 1910.

Lavista, F. "The medium-sized manufacturing enterprise (1927-81)", in Forms of Enterprises in 20th Century Italy. Boundaries, Structures and Strategies edited by A. Colli and M. Vasta Cheltenham-Northampton: Elgar, 2010: 248-269.

Mediobanca-Unioncamere, Le medie imprese industriali italiane (1999-2008) Milan: Mediobanca, 2011.

Menozzi, A., M. Gutiérrez Urtiaga and D. Vannoni, "Board composition, political connections, and performance in state-owned enterprises", Industrial and Corporate Change, 21, 1 (2011): 671-698.

Menzani, T. and V. Zamagni, "Cooperative networks in the Italian economy", Enterprise \& Society, 11, (2010): 98-127.

Nichele, G., Corporate governance e assetti proprietari nei gruppi cooperativi: evoluzione e aspetti problematici, M.Sc. Diss, Milan: Bocconi University 2010.

Nuvolari, A. and M. Vasta, "The Ghost in the Attic? The Italian National Innovation System in Historical Perspective, 1861-2011," Quaderni del Dipartimento di Economia Politica e Statistica, Università di Siena, No. 665 (2012).

Pavese, C. "Le origini della società Edison e il suo sviluppo fino alla costituzione del 'gruppo', 1886-1919”, in Energia e sviluppo. L'industria elettrica italiana e la società Edison, edited by B. Bezza, Turin: Einaudi, 1986: 25-169.

Pozzi, D., Dai gatti selvaggi al cane a sei zampe, Venice: Marsilio, 2009.

Rinaldi, A., "The Rise of a District Lead Firm: The Case of Wam (1968-2003)", Zeitschrift für Unternehmensgeschichte, 55, 1 (2010): 52-81.

Rinaldi, A., and M. Vasta. "The structure of Italian capitalism, 1952-1972: new evidence using the interlocking directorates technique”, Financial History Review, 12, 2 (2005): 173-198.

Rinaldi, A., and M. Vasta. "The Italian corporate network after the 'Golden Age' (1972-1983): from centrality to marginalization of State-owned enterprises" Enterprise \& Society, 13, 2 (2012): $378-413$.

Romano, R., L'industria cotoniera lombarda dall'Unita' al 1914, Milan: Banca Commerciale Italiana, 1992.

Sabbatucci Severini, P. Il capitalismo organizzato: il settore saccarifero in Italia, 1800-1945, Venice: Marsilio 2004.

Solimene, L., "Servizio universale, liberalizzazione dei mercati e regolamentazione dei servizi di pubblica utilità", Economia pubblica, 2 (2002): 34-55.

Toninelli, P.A., and M. Vasta, "State-owned enterprises (1913-72)", in Forms of Enterprises in 20th Century Italy. Boundaries, Structures and Strategies edited by A. Colli and M. Vasta CheltenhamNorthampton: Elgar, 2010: 52-86. 
Valotti, G., Imprese, istituzioni e regole nella produzione di servizi di pubblica utilità. Le condizioni per lo sviluppo della competitività, Milan: Franco Angeli, 1996.

Von Tunzelmann, G. N., "Big Business, Growth, and Decline", Journal of Economic History, 59, 3 (1999): 787-794.

Zamagni, V., "The Rise and Fall of the Italian Chemical Industry, 1950s-1990s", in The Global Chemical Industry in the Age of the Petrochemical Revolution, edited by L. Galambos et al., New York: Cambridge University Press 2007: 347-67.

Zamagni, V. and E. Felice, Oltre il secolo. Le trasformazioni del sistema cooperativo Legacoop alla fine del secondo millennio, Bologna: Il Mulino, 2006.

Zattoni, A., Le holding dei gruppi italiani a controllo familiare, mimeo, Milan: Bocconi University, 2012. 
${ }^{1}$ Colajanni, "Il capitalismo senza capitale".

${ }^{2}$ Colli, "A Tale".

${ }^{3}$ Amatori and Brioschi, "Le grandi imprese".

${ }^{4}$ Becattini, Industrial District.

${ }^{5}$ Colli and Vasta, "Large and Entangled".

${ }^{6}$ Federico, "Italy 1860-1940" Amatori and Colli, Impresa e industria; Giannetti and Vasta (eds.), Evolution of Italian Enterprises.

${ }^{7}$ Amatori, "Italy: the tormented rise".

${ }^{8}$ Giannetti and Vasta "Big Business"; Amatori, Bugamelli and Colli, "Italian Firms in History".

${ }^{9}$ Colli and Vasta, "Introduction".

${ }^{10}$ Giannetti and Vasta, "Big business"; Amatori, Bugamelli and Colli, "Italian Firms", 470-4.

${ }^{11}$ Amatori, Bugamelli and Colli, "Italian Firms", 472. Nuvolari and Vasta, "The ghost in the attic".

${ }^{12}$ Colli and Vasta (eds.), Forms of Enterprise.

${ }^{13}$ Amatori and Colli, "European Corporations"; Binda and Colli, "Changing Big Business".

${ }^{14}$ Colli and Rinaldi, "Institutions, Politics and the Corporate Economy", Battilani and Zamagni, "Co-operatives"; Fari and Giuntini, "Public Utilities".

${ }^{15}$ Colli and Vasta (eds.), Forms of Enterprise.

${ }^{16}$ Colli and Vasta, "Large and Entangled".

${ }^{17}$ Bonelli Lo sviluppo.

${ }^{18}$ Fear, Cartels.

${ }^{19}$ Romano, L'industria cotoniera lombarda.

${ }^{20}$ Sabbatucci Severini, Il capitalismo organizzato.

${ }^{21}$ Colli, "The Italian Brewing Industry".

${ }^{22}$ Battilossi, "Mercati e concentrazione".

${ }^{23}$ Amatori and Colli, Impresa e industria.

${ }^{24}$ Amatori, "Italy: the tormented rise".

${ }^{25}$ Castronovo, Fiat 18999-1999; Amatori and Bezza, Montecatini

${ }^{26}$ Pavese, "Le origini"; Amatori and Brioschi "Le grandi imprese", 121.

${ }^{27}$ Zamagni, "The Rise and Fall".

${ }^{28}$ Brioschi, Buzzacchi, Colombo, Gruppi di imprese.

${ }^{29}$ De Cecco, "La politica italiana delle privatizzazioni".

${ }^{30}$ Colli and Vasta, "Large and Entangled".

${ }^{31}$ Colli and Vasta, "Large and Entangled".

${ }^{32}$ For a detailed overview of the boundaries and the weight of SOEs in Italy in the $20^{\text {th }}$ century, see Toninelli and Vasta, "State-owned", tab. 3.4.

${ }^{33}$ Pozzi, Dai gatti selvaggi.

${ }^{34}$ Toninelli and Vasta, "State-owned", tab. 3.4.

${ }^{35}$ Colli and Vasta, "Large and Entangled".

${ }^{36}$ Rinaldi and Vasta, "The structure of Italian capitalism"; Ibid, "The Italian corporate network" .

${ }^{37}$ Barca and Trento, "State ownership".

${ }^{38}$ Toninelli and Vasta, "State-owned", tab. 3.4.

${ }^{39}$ Battilani and Zamagni, "Co-operatives".

${ }^{40}$ Menzani and Zamagni, "Cooperative networks".

${ }^{41}$ Battilani and Schröter (eds.), The Cooperative Business Movement.

${ }^{42}$ Nichele, Corporate governance.

${ }^{43}$ Battilani and Zamagni, "The Managerial Transformation".

${ }^{44}$ Battilani and Zamagni, "Co-operatives".

${ }^{45}$ Zamagni and Felice, Oltre il secolo: 95-96.

${ }^{46}$ Bertagnoni (ed.), Una storia di qualità.

${ }^{47}$ Nichele, Corporate governance, p. 45.

${ }^{48}$ Fari and Giuntini, "Public Utilities".

${ }^{49}$ Valotti, Imprese, istituzioni e regole.

${ }^{50}$ Solimene, "Servizio universale".

${ }^{51}$ Fari and Giuntini, "Public Utilities".

${ }^{52}$ Menozzi, Gutiérrez Urtiaga and Vannoni, "Board composition”.

${ }^{53}$ Colli, Il quarto capitalismo; Coltorti, "Medium-sized firms"; Mediobanca-Unioncamere, Le medie imprese.

${ }^{54}$ Lavista, "The medium-sized manufacturing enterprise (1927-81)", : 248-269.

${ }^{55}$ Colli, Il quarto capitalismo.

${ }^{56}$ On the integrating properties of ICT, see Von Tunzelmann, "Big Business".

${ }^{57}$ Zattoni, Le holding dei gruppi italiani. 
${ }^{58}$ Rinaldi, "The Rise of a District Lead Firm”.

${ }^{59}$ Hilferding, Das Finanzkapital.

${ }^{60}$ Amatori, "Entrepreneurial Typologies"; Colli and Rinaldi, 'Institutions'. 